\title{
Space majors: Towards new deals
}

\section{Bertrand de Montluc}

Senior Member of Association for Aeronautics and Astronautics (France), Member of the European Academy of Air \& Space, Former Director at the French Space Agency CNES, Lecturer at Paris University Sciences Po, international college (Scientific Humanities), Le Havre, France

\section{Email address:}

bertranddemontluc@yahoo.fr

\section{To cite this article:}

Bertrand de Montluc. Space Majors: Towards New Deals. International Journal of Astrophysics and Space Science. Vol. 2, No. 6, 2014, pp. 81-87. doi: 10.11648/j.ijass.20140206.11

\begin{abstract}
Space is nowadays conceived not only as important for scientific, cultural or security motivations but as a symbol of modernity, of political identity and as a strategic instrument on the international scene. That represents a new challenge for Europe puzzled by the weakening American leadership, the uncertainties of the Russian complex and the rise of the Asiatic nations. In such a context, while too many space policy experts see the space policies of the major space powers as rather conservative and "as usual", the author cross examines in five points the main policy lines of the space strategies of the US, Russia, China and Europe. Many things have changed in the last ten years and there are today new dynamics at work. Considering these evolutions, it is suggested to start thinking to the future policy lines of the major space powers: towards a broader competition, or the beginning of a new rationale for international co-operation?
\end{abstract}

Keywords: Space Exploration Long Term Strategies, Space Competition Rationale and Trends, International Space Policies, Space Powers

Space technology is an indispensable catalyser of action in many scientific and economic fields as well as an indispensable mean of intelligence for the political rulers in times of crisis. With the acceleration of new forms of economic competition and arms races in the Middle East and Asia, a number of nations decided to develop themselves such capabilities and to make space policy a key element of their national identity, of their 'posture' as the diplomats say, on the international stage.

At the same time, while the globalization process is accelerating, the utilization of space systems for civilian or commercial purposes is growing in importance, generating new ways of fulfilling more and more users' needs (telecommunications, earth observation and environment monitoring, weather forecast, navigation). The usefulness of the two components of space systems, military and civilian, for modern countries that are anxious to develop rapidly and to structure their identity as autonomous states has become manifest worldwide; it even encourages today some major powers to think about means of limitating for others than themselves the strategic advantages provided by the mastering of space systems (launchers and satellites), paving the way to a possible weaponization of space.

Thus the times when space exploration was seen as symbol of imperium for two dominant federations, the USSR and the US (the first satellite ever launched for the Russians, the first landing on the Moon surface by the Americans), and the times when later on space policies were understood as avenues for science, communications and earth observation ${ }^{1}$ tend to make room for a period where geopolitical considerations acquire a new weight in an international context of global competition. Space is nowadays conceived not only as important for social or cultural motivations but as a symbol of modernity, of political identity and as a strategic instrument on the international scene. That represents a new challenge for Europe puzzled by the weakening American leadership, the uncertainties for the future Russian complex and the rise of the Asiatic nations.

\section{More Actors, More Competition}

Space is affected by contradictory trends -globalization and nationalism- and also by an international environment in which the old order is contested and in which the balance of power is unstable. The willingness found in the previous decades to give priority to outer space exploration is somehow weakening,

\footnotetext{
${ }^{1}$ See the research works by Nancy Gallagher and John D. Steinbruner, for example, Reconsidering the Rules for Space Security, American Academy of Arts and Science, 2008.
} 
at least in western countries. For some years now we have been witnessing a tendency for several of the world's space programs, traditionally aimed at developing science programs or 'useful' space applications sometimes in co-operation or 'trans-continental partnership', to take on a more distinctly nationalistic character. The desire to co-operate in the field of large endeavors is decreasing. China, India, South Korea, and maybe others in the coming years, adopt mostly symbolic objectives for their programs as sign of scientific excellence, national pride or foreign influence. These countries have announced their intentions of putting their own citizens in orbit (even Malaysia), of going to the Moon and of participating in further space exploration missions.

At the same time, the same players, or others (Iran with the Safir and Kavoshgar launchers, North Korea (with the Taepodong and Unha rocket) are making no secret of their intention to acquire space capabilities for defense purposes, whether anti-missile (Japan) or anti-satellite systems (China, perhaps India). The absolute pre-eminence of America, Russia and Europe may soon be a thing of the past. A study by the Washington think tank CSIS showed that although only few nations have independent launch capability or the technology for manned flight, the number of players controlling their own satellite telecommunications systems has doubled since 1980 (Indonesia was one of the first and Vietnam the more recent, but there is also Arabsat, programs in Australia, Nigeria, South Africa, etc.). To be more specific there are now 27 countries with satellite-based earth observation resources, compared with three in 1980, not to mention the increasingly numerous countries which have their own image receiving stations for remote sensing systems, owing to the reduction in acquisition costs. A total of 49 civil actors worldwide have access to space $^{2}$.The world now has 25 space Agencies, large or small. States like Nigeria, Algeria, Argentina, Malaysia or Indonesia, have established space programs, as symbols of independence, national pride and the desire to inspire their youth. Moreover, governments have made available public budgets for R\&D or development of hardware as required, usually between $\$ 10$ and $\$ 60$ million, or more than $\$ 100$ million in the case of countries like Canada (358), Brazil (118) or South Korea $(317)^{3}$. In terms of public satellites launched between 1998 and 2007 by large regions of the world, Asia Pacific, Southern Asia, Middle East and Africa, Latin America would represent $25 \%$ of the total launched (445). Some analysts expect that for the next period (2008-2017) the ratio for the same regions could reach $32 \%$ of the forecast total (See Figure below).

The emerging countries are emerging fast, and they do not merely wish to take their place in the global economy but to be accorded the geopolitical role that they feel is theirs. Mastering space technology and the ability to be an actor in the exploitation and exploration of the outer space has become a key element in that strategy. The reason why they

\footnotetext{
${ }^{2}$ Space Security Index 2011 and 2012.www.spacesecurity.org

${ }^{3}$ Center for Strategic and International Studies, CSIS, Brad Glosserman, "Briefing of the working group on the health of the U.S. Space Industrial Base and the impact of export controls" (February 2008). And Euroconsult 2008, Government Space Markets, World prospects to 2017, pp.15 and 42.
}

move forward rather easily is also that the traditional leadership imposed by the Majors is changing: The US and Russia appears more reserved, Europe is taking a break and China is still lagging behind ... But these stands could change now that the geopolitical context is rapidly evolving towards a stiffer strategic posture of the main actors...

Projected Space Budget Distribution - 2030 (\%)

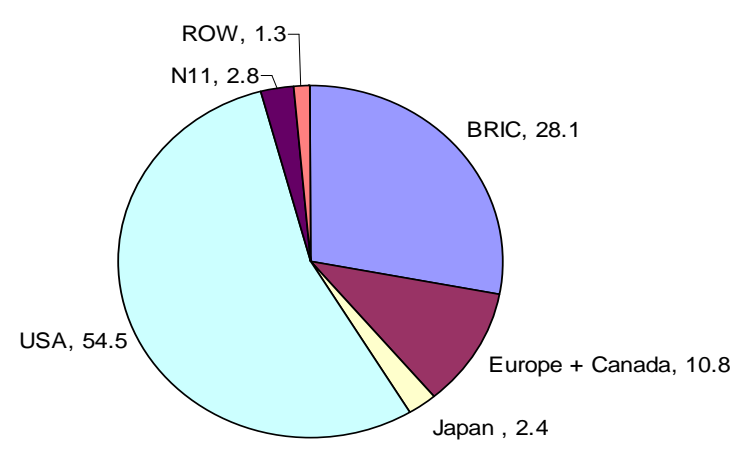

$\square$ BRIC $\square$ Europe + Canada $\square$ Japan $\square$ USA $\square$ N11 $\square$ ROW

(Source: International Space University, ISU, IISC/IAC-09.E6.3.13)

Fig 1. Projected Space Budget Distribution-2030(\%)

\section{The Major Space Powers}

If you consider the three main examples of states which have the dimension of continents (the United States, Russia and China) each possessing nuclear weapons, for which space is part of their strategic pride and national assets, and if you make a comparison with the positioning of Europe, quite different, it appears how difficult it is to envisage a significant move forward in favour of global space partnership even for very large projects such as exploring other planets.

Concerning the United States, first, the most remarkable geostrategic change in terms of policy, well beyond what is to be decided about NASA's future programs, was the implementation of the strategic "new triad" as defined by the Nuclear Posture Review of $2002 .{ }^{4}$ In the US, space is not only a series of technological instruments able to help the Administration and the President to boost the economy in ordinary times and make appropriate decisions in time of international crisis, but a full part of a more general geopolitical configuration. The Administration is anxious to lower the tone about the perspectives of space control and weaponization, but sticks to the point of the protection of the America's vital space assets. For example, a 'code of conduct' for the sake of maintaining a safe space environment as proposed today by the Europeans, if per se acceptable, must in their idea be compatible with the

\footnotetext{
${ }^{4}$ D.M. Gomley, "Silent retreat: The Future of U.S. Nuclear weapons", The Nonproliferation Review, July 2007, Vol.14, No.2. CRS Report for Congress, "U.S Strategic Nuclear Forces: Background, Developments, and Issues", A.F. Woolf, 5 September 2007. Also, armscontrol.org, "Nuclear Posture Review".
} 
objective of self protection and anyway should take the form of an enforceable treaty. ${ }^{5}$

In the civil field new orientations were given to NASA at the beginning of the years 2010 in order to give muscle to the American space programmer: no spectacular new starts for the human exploration maybe, but promotion of private initiatives in the space launch services business (Space X); confirmation of the International Space Station programmer largely beyond 2020 (about 3 B $\$$ per year); solid R\&T budget; planetary sciences with the James webb Space Telecope (a 100 times more capable successor to the Hubble Space Telescope for $600 \mathrm{M} \$$ till 2018) remaining a corner stone. The Curiosity/MSL/Discovery mission appeared recently as a demonstration of the persistence of the NASA's expertise in operating highly technical space operations. President Obama confirmed that he had no plan to come back to the Moon, and in 2011-2012 the Constellation programmer was canceled. The objective of the policy, though still rather vague, would be landing on Mars in 2030 with a mission to an asteroid before and development in the short term of a new heavy launcher $(S L S)$ and of an Orion crew capsule for deep space exploration. In November 2013, the White House released a new document called National Space Transportation Policy re-affirming the commitment to "assured access to space" with new entrants for EELV (evolved expendable launch vehicles). The FY 2015 Budget Request aims at getting 17, $5 \mathrm{~B} \$$ with the same priorities -the heavy launcher SLS and Orion (2, 7 B \$), commercial launchers $(848 \mathrm{M} \$$ ), with one new start in the field of planetary sciences (mission to Europa, moon of Jupiter). The Commercial Crew Integrated Capability Program (6, 8 B \$ for the transportation of the American astronauts to the Station to Boeing and Space $\mathrm{X}$ ) and a growing tendency to rely on the private sector show that the NASA's leadership is in evolution, even if some important risks are attached to such a policy (failures of the launch operations of Aerojet/Orbital Science's Antares and of the SpaceShip Two of Scaled Composite/Virgin Galactic in October, 2014).

Russia no longer has a complete arsenal of high-level operational space resources. Its space systems including the launchers are in some cases declining (5 failures of space systems in 2011, failure of the Proton heavy launcher in August 2012, failure of the upper stage Fregat of the Soyuz launcher in 2014). But Moscow's determination since 2000 to confirm that it can rely on its nuclear weaponry implies modernizations including its satellite technology. ${ }^{6}$ In addition, what is known of Russian perceptions about future war scenarios confirms this orientation. As early as 1993, the then Minister of Defense, P. Gratchev, observed that future wars would have to begin with aerospace operations. The Russian military heads consider space as a potential strategic theatre. There is a feeling in Russia that space resources are necessary to confront the others, to create or contain

\footnotetext{
${ }^{5}$ AS for the European stance, see B. de Montluc, "SSA: Where does Europe stand now?',Space Policy journal, Elsevier, 2012, 1-3.

${ }^{6}$ N. Sokov, "The origins of and prospects for Russian Nuclear Doctrine", The Nonproliferation Review, Vol. 14, No.2, pp.208-210.
}

antimissile systems and to keep a close watch on what is happening in space. ${ }^{?}$

Russia, benefiting from a generous economic growth of $7 \%$ a year after the financial crisis of 2008, has partly restored its navigation capabilities (Glonass). It develops a new launcher (Angara) and progressively modernizes its industry by grouping space firms in six major "holdings" On the opposite its ambitions concerning visible developments for human space exploration, beyond scientific research (such as projects of automatic research of life traces in outer space, such as the ExoMars project), seem dubious.

The Russian space budget, which was 25 years ago in the

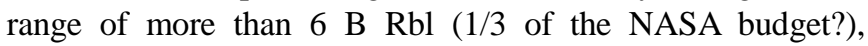
drastically fell in the years 1990 (to probably lower than 800 M\$ (300 M\$ in 2002). After the 2008 international financial crisis, the civil budget -which includes the federal budget of the space agency (earth observation and telecommunications), plus the launching sites and plus Glonass- progressively increased by a factor of five, up to $1,6 \mathrm{~B} \$$ in 2010 and maybe $3,4 \mathrm{~B} \$$ in 2013. About seventy satellites would be in orbit now. The space defense budget which suffered a lot in the twenty last years apparently progresses step by step but its amount remains classified. Radar (Kondor, Obzor) and optical (Ressource) imagery, often dual-use systems, are operated; so are Tselina/Pion for electronic eavesdropping, Oko/Cosmos, Molnya and a new EKS Toundra for early warning, Lotos for oceanic surveillance, Radouga/Globus for GEO telecommunications; Nariad for probatory ASAT tests... However the economic growth, already reduced in 2012 (3, $4 \%$ ), is today at $1,4 \%$, soon close to zero. The 2014 Crimea and Ukranian crisis brought some turbulence in the policy. $<$ And the US and Europe are more than reluctant to let Russian leaders act as if nothing had happened. The price of gas is getting lower and agai, as in 2008, inflation is increasing and the currency is going down. Moree specifically, the trouble introduced in the production of launchers, which are partly or completely built in Ukraine (Dniepopetrosk facility, for Zenit, Cyclon, Dniepr ...), is to be assessed. Recently, because of a wrong doing in the construction of the fuel alimentation of the Soyuz launcher Fregat upper stage (though till now reliable), two satellites of the European GNSS Galileo constellation have been put on a wrong orbit. A few months later an Orbital launcher used to carry a fret vehicle to the International Space Station (Antares) had to be destroyed a few minutes after the kick off because of a failure of a Russian engine powering the launcher (October 2014).

As for China, the country inherited the Soviet space program to a great extent and made an intensive use of Russian space technology in 'heritage', in particular the Shenzou manned spacecraft. Yet China does not possess the resources provided by the scientific and technical complex that existed in

\footnotetext{
${ }^{7}$ M. Fitzgerald, "The impact of the military-technical revolution on Russian military affairs", report for the Hudson Institute (vol.1, 20/8/1993).

${ }^{8}$ The French Institute for the History of Space (IFHE), Paris, headed by Ch. Lardier, is gathering comprehensive documentation and analysis for a book about Russia and France co-operation in space in the past forty years to be published in 2015.
} 
the former Soviet Union. Its space program is a central government-steered management to an extent that cannot be compared with Moscow's steering of its own Soviet militaryindustrial sector. It is of course even truer if you compare the US space complex and budgets. On the other hand, China is benefiting from the dynamism of its market industrial sector and of reliable public budgets, if not huge, however provided on dual sources and is timely affected. It has overhauled aerospace project management structures and procedures. As an emergent great power, it looks forward to acquiring more military and security space capabilities and the geostrategic 'posture' which comes along. And, finally, the main incentive, PRC is able to present a strategic vision and a clear political motivation for investing in space technology -which seems not to be the case of the traditional competitors, would they be the Americans, Russians or Europeans.

China is clearly seeking to acquire by all possible means the modern space know-how required to gain a command of civilian applications for its own use and to give work to the Chinese industry, in fields like earth observation, meteorology, satellite television, telecommunications and navigation (Beidou constellation network of 16 GPS like navsats) but also space sciences for the sake of its own national pride in the framework of the international scientific competition. In addition it is developing projects for the use of space in the field of defense (in 2014, launch by a CZ-7 of a "earth observation" Yaogan 21 military satellite built by the Chinese Academy of Space Technology/CAST). It even successfully experienced, in January 2007, an anti-satellite (ASAT) weapon test directed on one of its own aged satellite; and it is said to have experienced a new test in 2013. At the same pace, a 'Man in space' program is rapidly shaping up. China conducts, since 2008, human flights on board the Shenzhou vehicle. In 2011, the same vehicle, Shenzhou VIII, for the first time provided two docking/rendezvous with the Tiangong orbital module. In 2012, the first female Chinese astronaut, Liu Yan, flew on-board Shenzhou IX. In 2013 China succeeded for the sake of its space exploration program to land the Chang'e-3 spacecraft and its Yutu rover on the Moon. Chang'e-5 launched atop a Long March 3C rocket completed a flyby of the Moon before swinging back to earth on October 31, 2014. Above all, PRC possesses the high-performance Long March space launch vehicle which is regularly increasing its performances. In 2010, 15 launches were realized, including the launching of the Change lunar probe. In 2011, 19 launches were performed which represents $22 \%$ of the world launch activity! Today China is testing the second stage of its future Chang Zheng launcher (CZ-7, able to launch 13t. in low orbit) which will launch the Taizhou cargos to be docked to the future Tiangong $2 \& 3$ stations. The overall Chinese space budget would in the range of $\$ 3$ billion (2014).

Finally, since it is unable to keep up with the United States in the field of modern conventional weapons and confronted with the future Missile Defense systems, China attaches great importance to maintaining the credibility of its deterrence potential and to catching up in areas where it lags behind (systems for command and control, surveillance, guidance, accuracy and miniaturization of space technologies ${ }^{9}$ ). As shown by its ASAT anti-satellite missile tests, China is seeking to acquire counterspace technologies and asymmetric capabilities to compensate for America's advantages elsewhere and to be a credible leader player in the field of civil human and robotic space exploration ${ }^{10}$. There is no doubt today that China includes space in its strategic arsenal, and in its international political stance. The willingness of the Party leaders to demonstrate that in the space field they are not only wishing autonomy but also of leadership sends a message of importance to other dominant space powers.

In the ten or fifteen years to come China might have a unique window of opportunity for achieving for its own such performances, because of the relative weakness of commitment of its competitors, the US, Russia, and Europe as well. ${ }^{11}$

Europe has a partially-integrated successful space policy through the civilian programs (Ariane, science, earth observation and environment) run by the European Space Agency, a technical intergovernmental international organization (ESA). More, the space policy is today, by treaty, one the competences of the European Union ('European Space Policy', ESP). For the time being, the Commission is still regularly meeting serious difficulties in getting decent funding for its 'flagship' programs, Galileo (GNSS) and GMES (Global Monitoring for Environment and Security). But generally speaking, in terms of policy, the result of the previous forty years is spectacular, both in the field of industrial co-operation (space industrial companies are largely merged) and institutional consolidation (framework agreement between ESA and the EU). Programs considered as strategic for national sovereignty are, in parallel, run by one or a few states (e.g. Helios). Although Europe has taken the first steps towards a common defense stance with the European Security and Defense Policy (ESDP), it does not possess an army or a nuclear deterrent, consequently Europe's space-based military capability and that of its member states is not integrated in a unique comprehensive

\footnotetext{
9 Jin-dong Yuan, "Effective, reliable, and credible: China's Nuclear Modernization", Nonproliferation Review, Vol.14, No.2, July 2007 (pp.226-301). K. Pollpeter, "Building for the future: China's progress in space technology during the tenth 5-year plan and the U.S. response", March 2008 (www.strategicstudiesinstitute.army.mil/).

${ }^{10}$ See publications by Joan Johnson-Freese, in particular The Chinese Space program: A Mystery within a Maze, New York, Krieger Publishing, 1998. And A. Tellis for the Carnegie Foundation, "China's Military Space Strategy", Survival, Vol.49 No.3, Autumn 2007. Also, several Chinese authors, for example, Bao Shixiu, "Deterrence Revisited: Outer Space", China Security, winter 2007, pp. 211 (2007 World Security Institute). B. de Montluc's intervention at the F. Godement Paris research seminar Asia Centre, "Chinese Space Policy: Military and Strategic Implications", June 2008.

13 The ambitions and expertise of China in the space field was often questioned some years ago; it is no longer an issue. It seems also that in the last period the ruling Communist Party protected the interest of the Military, including the forces dedicated to the building and deployment of space capabilities. This is coherent with the political analysis made by the best think tanks (see F. Godement, " $18^{\text {th }}$ Congress: Expectations on Hold", November 2012, Asia Centre and European Council for Foreign Relations, centreasia.eu, ecfr.eu).
} 
Europe Defense Strategy ${ }^{12 .}$ At the national level, programmes such as Syracuse and Helios in France, Cosmo in Italy, SARLupe in Germany, meet however the main strategic needs. At the European Union level, the definition of space capacities for the security forces will likely be in the future standardized by the European Defence Agency (EDA). The relevant EU authorities would be responsible of coordinating the requirements in certain fields like surveillance or telecommunications ${ }^{13}$.

The willingness of Europe to be a major stakeholder in the field of human exploration of the Universe, which should be the next step to its global ambitions, is still to be acted through political and programmatic choices. For the time being Europe having given up years ago the ambition to build its own shuttle, is sticking to the objective of excellence in space sciences (Rosetta mission to the Comet 67P, later ExoMars) and competitivity in the field of launchers (Ariane 5ME and Ariane 6).

\section{Questioning the Concept of Leadership in Space}

Space technology is not in itself the solution to all the problems, societal or security concerns, that nations in an ultracompetitive world need to address today by themselves. Nevertheless space has de facto become in the last years a key component of modernity in many domains of economic and social life (from television by satellite to data transmission worldwide, from weather forecasting to high-resolution ground observation, from precise localization to monitoring of the environment). Possessing space capabilities appear also, particularly in the most dynamic regions of the world, as symbolic of leadership. After the Russians and the Americans in the sixties, Europe in the eighties, Asia today would like to send men in space and master the technologies of space transportation and space for defense. More generally, in a geostrategic context where international crises, violence and wars are more than ever present, a space program appears as a mark of distinction, a sign of belonging to the triple A class of competitive nations, at last a signal of mastering of one of the most sophisticated modern high technology capabilities. For the more powerful, eager to show their authority and their ability to be the leader of a region space technology may even appear as a critical component of their diplomatic and defense policies. Therefore, it is not likely that these countries will neglect investments for the procurement of modern space equipment which will give them decisive advantages in situation of military tension or international crisis. Their priority is not fair partnership or exploring outer space together. Concerning the specific field of human flights -man orbiting our planet, human space far reaching exploration initiativesthe question is controversial among those developed countries which have already proved that they possess the capability of

\footnotetext{
${ }^{12}$ For an outsiders' view of European capabilities, see "European Military Space Capabilities", T. Hitchens \& T. Valasek, CDI, Washington DC, March 2006.
}

undertaking such achievements. It is true that 'high-speed' developing nations like China, India and maybe other developing countries later on, have plans to send their nationals in orbit and to land on the Moon's surface. For them, this would be a feat, a first time, demonstration of their maturity and ability to build complicated reliable systems.

The leader in that field, after the decline in Russia, remains of course the U.S. at least in terms of advanced technologies. However the U.S., precisely, has a position more reserved than some years ago. The 2010/2012 orientations given by the Administration in Washington for the space programme, though promoting R\&T, launchers and more private initiatives, were full of ambiguity. NASA is not prepared to give-up the ultimate leadership in that symbolic field means of American self-affirmation. But political leaders on the Hill, Democrats and also some pragmatic Republicans, who have dreams of a very different nature than going to the Moon, appear to be reluctant to invest tax-payer money in such space 'adventures'. They probably feel that the military and aerospace industrial complex has been largely funded for years if not decades. That is, perhaps, the reason why the White House decided to cancel the Constellation programme dedicated to the 'play back' exploration of the Moon. A new assessment of the way it intends to define and materialize its leadership has to be worked out. The white paper published at the end of 2012 by the US National Research Council dealing with 'new strategic direction for NASA' clearly indicated that 'There is no national consensus on strategic goals and objectives for NASA". ${ }^{14}$ Now that the private sector in the field of launchers appears after the failure of October 2014 as more fragile than thought, and that the NASA institutional program called 'Space Launch System' is lacking of funds to be ready before 2019, the predictability of the NASA's strategy and its ability to show the ways to the other Majors have again decreased. Some new tracks are to be explored, possibly with foreign partners. Since the ultimate objective of the policy would be landing on Mars in 2030 (with a mission to an asteroid before), the short term plans aim at showing the sophistication of scientific missions such as Curiosity/Mars Lander/Discovery (August 2012) and at maintaining an operational capability for American astronauts to fly in orbit. This seems pretty much in line with the objective of conservation at a lower cost of the traditional leadership role in that field -though without the same desire to appear as the sole leader.

A few tricky questions usually put beneath the table remain: which form will the US leadership take in the years to come and related to which values? Is the strategy going to come back to a more generous and less 'isolationist' line of conduct (as in the sixties)? If so, it would encourage the establishment of international partnerships (China, India, Japan, Russia or Europe) for some visible and costly second generation space exploration initiatives - to settle on the Moon ${ }^{15}$, to retrieve more samples from the Mars surface, or to land on its surface

\footnotetext{
${ }^{14}$ The PDF is available from The National Academies Press at www.nap.edu 17 A permanent international base on the Moon for four persons would cost 35 billion \$, plus 7 billion for maintenance and exploitation.
} 
with men on-board, and also for sharing the burden of monitoring the Earth climate and Earth resources. Or on the contrary will the next Administration in Washington DC care for more defense and hi-tech budgets in order to fully restore the American super power?

What a challenge for Europe, presently embedded in endless discussions about its future objectives included in the field of launchers!

\section{Towards New Deals}

To assume correctly if 'new deals' are to be adopted or not by the major space powers in the years to come after the transition period of 1990-2015 depends of how you figure out two parameters or respond to two questions: first, is the reluctance of the Administration in Washington to focus the American leadership on ambitious space exploration projects going to last -even if international geo-strategic competition increases? Second, is the growing ambitions and selfconfidence of Asia in space technology going to result in a competition or a co-operation process with the West? Europe, and Russia are carefully observing these possible evolutions.

As for Asia, a regional competition between space actors inside the region is already visible. For example, India, that used to be an efficient but rather modest space player, enhances its position and ambitions. The Indian space agency (ISRO) successfully inserted its Mars Orbiter Space craft into Mars orbit (2014) and is operating a mission called Chandrayaan designed to orbit the Moon ... The willingness of the rising countries to benefit from the applications of space technologies for their domestic development or security also constitutes a powerful incentive to move ahead in this sector which corresponds to the interests of the aeronautics and armament industries. Signals are sent to Western powers, the US and Europe, that they should more consider the ambitions of these new stakeholders and propose larger co-operations (even if the risk for western industry of damaging technology transfers cannot be excluded). However, one should be sure that these rising stakeholders will be inclined to share with the other international partners the burden and the profits of common projects for the benefit of the entire human community. It is still early to give a definite answer to such a sensible question. The major space powers should realize that such issues are to be seriously examined by their experts in the near future.

Europe on the other hand has achieved a remarkable regional economic integration and stabilized peaceful relations with its foreign partners, as exemplified by the attribution of the Nobel Price for Peace by the Stockholm committee in December 2012. In the space sector, it showed as early as the seventies and eighties that it knew how to build consensus and arrange an original organization to provide its member states with successful programs in the fields of science, $\mathrm{R} \& \mathrm{D}$, space applications (telecommunications, meteorology, earth observation, now GNSS) and above all access to space (Ariane). Later on, at a slower pace and with a smaller number of participants it undertook to develop its own means of observation and telecommunications for military uses. Today one can see the results of both efforts, even if they are limited. It is true that in the visible but costly field of human space exploration Europe does not appear committed to ambitious programs, after a failed tentative demonstration in the eighties (Hermes space shuttle project). In that field, as well as in the project of building space and ground infrastructures for monitoring of the Climate and the Environment, Europe presently pauses for consolidation. More public money and food for new thoughts will be needed to go beyond. For the time being, ESA and its member states are committed mainly to protect the assets which are the two pillar of the European strength: science and launchers. As for Science, Rosetta is the flagship: the Philae lander landed on the surface of the 67P/Churyumov-Gerasimenko comet flying $500 \mathrm{KM}$ from Earth on November 12, 2014. In the field of launchers, after more than sixty successful launches, Ariane5 needs refurbishment. At the end of the year 2014, a ministerial ESA conference of member states decided which configurations are better suited to procure a cost effective launcher, able to compete with the American Space $\mathrm{X}$ and the Russian launchers, and fully adapted to the evolution of the satellite market. The space agency of the most advanced state in that field, CNES, had advocated for an option of all solid fuel monocharge launcher. Industry, namely Safran and Airbus Defense \& Space proposed in July 2014, proposed a more logic and flexible solution with two versions of Ariane 6 in line with the tradition of the Ariane family (launch of 2 satellites, cryogenic engines, with solid fuel strap-on boosters, and a re-ignitable upper stage. In December, the solution of Ariane 6 as dual-launch system based on the cryogenic technology was endorsed by the Ministers after a fiece fight between the Industry that had fought for such a formula and agencies which were in favour of a full solid fuel architecture.

Finally, for the majority of space powers, the trigger to lower or accelerate the pace in the coming years will be the willingness of China. After landing a taikonaut on the Moon and correctly mastering spectacular space orbit probatory operations, after flexing its muscles, time could be ripe for China to adopt an more open and co-operative attitude on topics like monitoring the earth environment, exploring Mars and the Universe. A change in the general politico-strategic posture of the United States -with a clear vision, more openness to multilateral diplomacy and acceptance of the principle of fair industrial partnerships- would attract if not Russia but perhaps China and Europe.

At a larger scale, such new stances would stimulate the international enthusiasm for space endeavors after so many depressing years of international and economic crisis ${ }^{16}$.

\footnotetext{
${ }^{16}$ The White paper above mentioned released in December 2012 by the US National Research Council on "NASA's Strategic Direction" stresses that to be a leader does not mean to be dominant and that to be a partner does not mean to be a follower, because "leadership is more nuanced today than during the Cold War". In its conclusions, one Option is clearly described by the Committee of experts that is: "Commit for the long term to more cost-sharing parnerships with .../... international partners."
} 


\section{References}

[1] Joan Johnson-Freese, The Chinese Space Program: A Mystery within a Maze, New York, Krieger Publishing, 1998

[2] A.Tellis, "China’s Military Strategy", Survival, Vol.49, N³, Autumn 2007

[3] David A. Mindell, Scott A. Uebelhart, Asif A. Siddiqi, Slava Gerovitch, The Future of Human Space flight: Objectives and Policy Implications in a Global Context. American Academy of Arts and Science, 2009

[4] Evan S. Meideros, Roger Cliff, Keith Crane, James C. Mulvenon, A New Direction for China's Defense Industry, RAND, 2005

[5] Benjamin S. Lambeth, Mastering the Ultimate High Ground, RAND, 2003

[6] Yearbook on Space Policy, ESPI, Springer, 2010

[7] P. Ehrenfreund, N. Peter, K.U. Schrogl, J.M. Logsdon, “Cross-

Cultural management supporting global space exploration", Elsevier, Acta Astronautica 66 (2010) 245-256

[8] CDI,The Bush National Space Policy: Contrasts and Contradictions, October 13, 2006

[9] UNIDIR, Space Security 2010: From Foundations to Negotiations, U.N. July 2010

[10] Space Security Index 2012, Project Ploughshares (http://www.space security.org/publications.htm)

[11] U.S. National Research Council, New Strategic Direction for NASA, National Academies Press (www.nap.edu)

[12] B. de Montluc, Asia and Europe Facing the Technological Revolution, Novinka, New York, Nova Science Publishing, 2013

[13] B. de Montluc, A New International Strategic Context for Space policies, Novinka, New York, Nova Science Publishing, 2011

[14] S. Kondapalli, China's Military and India, New Delhi, Pentagon Press, 2012 